comparison of counts between cards on American types and cards on Indian types in the same cardroom), and we have recently obtained evidence of a marked increase in the bacterial content of certain American and Brazilian cottons in the 1950 season as compared with 1949.

\section{Summary}

Counts of airborne bacteria have been made at various sites in cotton mills. They are exceptionally high in the card-rooms and at pre-carding processes but much less at the spinning and later processes. They are comparatively small in a waste mill cardroom but rather higher in the devil-room.
At all sites in a rayon mill the counts were indistinguishable from control counts.

In cotton mills the general level of counts depends on the source of the cotton and tends to be highest with American types; even for any one type it probably also depends on the crop year.

REFERENCES

Bourdillon, R. B., Lidwell, O. M., and Thomas, J. C. (1941). J. Hyg., Lond., 41, 197.

Caminita, B. H., Baum, W. F., Neal, P. A., and Schneiter, R. (1947). Publ. Hlth Bull., Wash., No. 297.

Furness, G., and Maitland, H. B. (1952). British Journal of Industrial Medicine, 9, 138. Prausnitz, C. (1936). Spec. Rep. Ser., med. Res. Coun., Lond.,
No. 212.

\title{
II. DETERMINATION OF TYPES OF VIABLE BACTERIA BY
} MARY HAMLIN

\author{
From the Shirley Institute, Manchester, British Cotton Industry Research Association
}

(RECEIVED FOR PUBLICATION JUNE 9, 1952)

An examination of the types of bacteria present in the air has been made in cotton mills using cottons of various origins. The organisms were collected on solid media in a Bourdillon type slit sampler and exposures were adjusted so that no plate from which subcultures were made carried more than 200 colonies. In all cases the medium was made up with $5 \%$ agar since at lower concentrations some colonies tended to spread.

Samples were taken in two cotton spinning mills. The first of these was visited twice and samples were collected in the card-room and at various other sites. Blood and nutrient agar were used in each case, and on the second occasion anaerobic as well as aerobic incubation was employed. One visit only was paid to the second mill and samples were only taken in the card-room ; blood and nutrient agar plates were exposed, some being incubated aerobically and others anaerobically.

In order to find whether the distribution of genera changed substantially as the cotton reached later stages of processing, visits were also made to a waste spinning mill and to two weaving sheds. The results from the spinning mills had shown that there was no significant difference between the types found on blood agar and those on nutrient agar and also that no obligate anaerobes were detected ; therefore on these later visits only aerobic cultures on nutrient agar were examined.

Details are given in Table 1.

After incubation colonies were subcultured from the aerobic plates to slopes, and from anaerobic plates to stabs ; those from blood agar plates to blood and nutrient agar, those from nutrient agar plates to this medium only. It was found that all the organisms would grow well on nutrient agar slopes, and the cultures were therefore maintained in this way. The organisms were assigned to their genera according to Bergey's classification (Bergey, 1948). The results are given in Table 2. The numbers of colonies examined and on which the counts per cubic foot were based are shown in brackets. High absolute accuracy is not claimed and the figures are intended for comparison within the table. For the less abundant types of organisms the number of colonies was very small and here in particular the accuracy is low.

\section{Discussion}

The investigation showed that the bulk of the organisms in the card-room air belonged to those genera which are commonly associated with soil and water, especially the former. No true anaerobes were isolated, and organisms commonly found. in the respiratory tract were virtually absent.

The genus Bacillus always predominated in the aerobic cultures, but the genus next in order of abundance has varied. The data are not sufficiently extensive to show whether the variation arose from differences in mill conditions or from the different mixings of cotton.

The total count based on anaerobic cultures was one-fifth or less of that obtained with aerobic cultures. Bacillus was very much suppressed but 
TABLE 1

\begin{tabular}{|c|c|c|c|c|c|c|}
\hline No. of Mill $\dagger$ & 1 (1st Visit) & 1 (2nd Visit) & 16 & 17 & 18 (1st Visit) & 18 (2nd Visit) \\
\hline Work in Progress & Cotton spinning & Cotton spinning & Cotton spinning & Waste spinning & Weaving & Weaving \\
\hline $\begin{array}{l}\text { Sites at which } \\
\text { Plates } \\
\text { Exposed }\end{array}$ & $\begin{array}{l}\text { Card-room } \\
\text { Blow-room } \\
\text { Speed frame room }\end{array}$ & $\begin{array}{l}\text { Card-room } \\
\text { Ring-room }\end{array}$ & Card-room & $\begin{array}{l}\text { Card-room } \\
\text { Devil-room }\end{array}$ & Weaving shed " $T$ " & Weaving shed " $\mathrm{O}$ " \\
\hline Type of Cotton & $\begin{array}{l}58 \% \text { American } \\
28 \% \text { Egyptian } \\
14 \% \text { other growths }\end{array}$ & $100 \%$ American & $100 \%$ Sudanese & Mixed waste & American & $\begin{array}{l}\begin{array}{c}\text { Mixed. } \\
\text { sited ampler } \\
\text { among }\end{array} \\
\text { looms weaving } \\
\text { Egyptian } \\
\text { cotton }\end{array}$ \\
\hline $\begin{array}{l}\text { Culture* } \\
\text { Conditions }\end{array}$ & $\begin{array}{l}\text { N.A. } \\
\text { B.A. }\} 47^{\circ} \mathrm{C} \text { hrs. }\end{array}$ & $\begin{array}{l}\text { N.A. } \\
\text { B.A. }\left\{\begin{array}{l}37^{\circ} \mathrm{C} . \\
96 \mathrm{hrs} . \\
\text { N.An } \\
37^{\circ} \mathrm{C} . \\
\text { B.An }\end{array} 72 \mathrm{hrs} .\right.\end{array}$ & 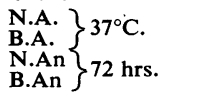 & $\begin{array}{l}\text { N.A. } \\
90 \text { hrs. }\end{array}$ & $\begin{array}{l}\text { N.A. } 37^{\circ} \mathrm{C} . \\
90 \text { hrs. }\end{array}$ & $\begin{array}{l}\text { N.A. } 37^{\circ} \mathrm{C} . \\
90 \mathrm{hrs} .\end{array}$ \\
\hline Notes $\ldots$ & $\begin{array}{l}\text { Sampling poor } \\
\text { owing to small } \\
\text { number of plates } \\
\text { examined }\end{array}$ & $\begin{array}{l}\text { Number of plates } \\
\text { increased to im- } \\
\text { prove sampling }\end{array}$ & $\begin{array}{l}\text { Number of plates } \\
\text { again increased } \\
\text { to improve sam- } \\
\text { pling }\end{array}$ & - & 一 & - \\
\hline
\end{tabular}

* $\mathbf{N}=$ nutrient agar ; $\mathbf{B}=$ blood agar ; $\mathbf{A}=$ aerobic incubation ; $\mathbf{A n}=$ anaerobic incubation.

+ The numbering of the mills is the same as that used by Drummond and Hamlin in the first paper of this series.

TABLE 2

NUMBERS OF ORGANISMS (COUNTS PER CUBIC FOOT)

\begin{tabular}{|c|c|c|c|c|c|c|c|c|c|c|c|c|c|c|c|}
\hline Mill & Site & $\begin{array}{c}\text { Type } \\
\text { of } \\
\text { Incu- } \\
\text { bation }\end{array}$ & $\begin{array}{c}\text { Total } \\
\text { Count } \\
\text { (per } \\
\text { cu. ft.) }\end{array}$ & Bacillus & $\begin{array}{c}\text { Ach- } \\
\text { romo- } \\
\text { bacter }\end{array}$ & $\begin{array}{c}\text { Flavo- } \\
\text { bacter- } \\
\text { ium }\end{array}$ & $\begin{array}{c}\text { Aero- } \\
\text { bacter }\end{array}$ & $\begin{array}{c}\text { Coryne- } \\
\text { bacter- } \\
\text { ium }\end{array}$ & $\begin{array}{c}\text { Micro- } \\
\text { coccus }\end{array}$ & $\begin{array}{l}\text { Actino- } \\
\text { myces }\end{array}$ & $\begin{array}{l}\text { Pseudo- } \\
\text { monas }\end{array}$ & $\begin{array}{l}\text { Sar- } \\
\text { cina }\end{array}$ & $\begin{array}{l}\text { Esche- } \\
\text { richia }\end{array}$ & $\mid \begin{array}{c}\text { Strepto- } \\
\text { coccus }\end{array}$ & $\begin{array}{l}\text { Failed } \\
\text { to Sub- } \\
\text { culture } \\
\text { or Died } \\
\text { before } \\
\text { Identi- } \\
\text { fication }\end{array}$ \\
\hline \multirow[t]{3}{*}{$\begin{array}{l}\text { No. } 1 \\
\text { 1st } \\
\text { Visit }\end{array}$} & $\begin{array}{c}\text { Card- } \\
\text { room }\end{array}$ & $\mathbf{A}$ & $\begin{array}{l}1,800 \\
(200)\end{array}$ & $910(102)$ & 330 (37) & $170(19)$ & $120(14)$ & $44(5)$ & $18(2)$ & $18(2)$ & $18(2)$ & - & - & - & $150(17)$ \\
\hline & $\begin{array}{l}\text { Speed } \\
\text { frames } \\
\text { room }\end{array}$ & $\mathbf{A}$ & $\begin{array}{r}540 \\
(59)\end{array}$ & $200(22)$ & $130(14)$ & $100(11)$ & $36(4)$ & $9(1)$ & $27(3)$ & - & 一 & 一 & 一 & - & $36(4)$ \\
\hline & $\begin{array}{l}\text { Blow- } \\
\text { room }\end{array}$ & $\mathbf{A}$ & $\begin{array}{l}1,200 \\
(124)\end{array}$ & $550(59)$ & $230(25)$ & $190(20)$ & $65(7)$ & - & $93(10)$ & - & - & - & 一 & 一 & 28 (3) \\
\hline \multirow[t]{4}{*}{$\begin{array}{l}\text { No. } 1 \\
\text { 2nd } \\
\text { Visit }\end{array}$} & $\begin{array}{l}\text { Card- } \\
\text { room }\end{array}$ & $\mathbf{A}$ & $\begin{array}{l}6,200 \\
(235)\end{array}$ & $3,900(149)$ & $110(4)$ & $27(1)$ & $\overline{580(22)}$ & $260(10)$ & $\overline{110(4)}$ & $110(4)$ & - & 一 & 27 (1) & - & $1,100(40)$ \\
\hline & $\begin{array}{l}\text { Card- } \\
\text { room }\end{array}$ & An & $\begin{array}{l}1,600 \\
(202)\end{array}$ & $210(27)$ & $300(38)$ & $360(46)$ & $300(38)$ & $47(6)$ & $8(1)$ & - & - & $16(2)$ & $40(5)$ & 一 & 310 (39) \\
\hline & $\underset{\text { room }}{\text { Ring- }}$ & $\mathbf{A}$ & $\begin{array}{r}220 \\
(245)\end{array}$ & $140(152)$ & $5(6)$ & $1(1)$ & $15(17)$ & $12(13)$ & $6(7)$ & - & - & 1 (1) & - & - & 43 (48) \\
\hline & $\begin{array}{l}\text { Ring- } \\
\text { room }\end{array}$ & An & $\begin{array}{r}41 \\
(200)\end{array}$ & $2(8)$ & $9(43)$ & $16(80)$ & $8(37)$ & $1(5)$ & $<1$ (1) & - & 一 & - & - & - & $5(26)$ \\
\hline \multirow[t]{2}{*}{ No. 16} & $\begin{array}{l}\text { Card- } \\
\text { room }\end{array}$ & $\mathbf{A}$ & $\begin{array}{l}2,900 \\
(480)\end{array}$ & $2,300(390)$ & $120(21)$ & - & - & $12(2)$ & $42(7)$ & $230(38)$ & - & - & - & - & $130(22)$ \\
\hline & $\begin{array}{l}\text { Card- } \\
\text { room }\end{array}$ & An & $\begin{array}{r}170 \\
(136)\end{array}$ & $42(34)$ & $16(13)$ & 73 (59) & $15(12)$ & $1(1)$ & $1(1)$ & $1(1)$ & - & 1 (1) & - & $1(1)$ & $16(13)$ \\
\hline \multirow[t]{2}{*}{ No. 17} & $\begin{array}{l}\text { Card- } \\
\text { room }\end{array}$ & A & $\begin{array}{r}230 \\
(400)\end{array}$ & $220(376)$ & $2(4)$ & - & $2(4)$ & $1(1)$ & $8(13)$ & - & - & - & - & - & $1(2)$ \\
\hline & $\begin{array}{l}\text { Devil- } \\
\text { room }\end{array}$ & $\mathbf{A}$ & $\begin{array}{l}1,700 \\
(400) \\
\end{array}$ & $1,200(277)$ & 83 (19) & $4(1)$ & $26(6)$ & $148(34)$ & $161(37)$ & $70(16)$ & - & $30(7)$ & $9(2)$ & - & - \\
\hline \multirow[t]{2}{*}{$\overline{\text { No. } 18}$} & $\begin{array}{l}\text { Weaving- } \\
\text { shed T }\end{array}$ & A & $\begin{array}{r}246 \\
(200)\end{array}$ & $213(173)$ & $2(2)$ & $1(1)$ & $5(4)$ & $6(5)$ & $14(11)$ & $4(3)$ & - & $1(1)$ & - & - & - \\
\hline & $\begin{array}{l}\text { Weaving } \\
\text { shed O }\end{array}$ & $\mathbf{A}$ & $\begin{array}{r}148 \\
(205)\end{array}$ & $87(121)$ & $11(15)$ & $5(7)$ & $3(4)$ & $12(17)$ & $19(26)$ & $4(6)$ & - & $3(4)$ & - & - & $4(5)$ \\
\hline
\end{tabular}

$\mathbf{A}=$ aerobic. $\quad$ An $=$ anaerobic

Number of colonies on which each figure is based given in brackets.

The nutrient and blood agar counts are not statistically significantly different and have been combined in this table. The counts are given to the first two significant figures. 
the count of Flavobacterium was significantly larger. The latter was also true in some cases of Achromobacter and Aerobacter. The distinction between Achromobacter and Flavobacterium is slight and not always certain.

There can be no doubt that the genus Bacillus is predominant in the card-room and that the remaining organisms consisted almost entirely of Achromobacter, Flavobacterium, Aerobacter, Corynebacterium, Actinomyces, and Micrococcus. This is true also of the distribution of genera in the weaving sheds and waste mill in which no types were found which were not already represented in the card-room.

Statistical analysis of the aerobic counts of Bacillus expressed as percentages of the total aerobic counts did not establish any significant difference between the two visits to Mill No. 1 (the data for the first visit are rather sparse), although the cotton mixing had been altered ; the increase in percentage on moving to Mill No. 16 was significant at the $1 \%$ level.

The airborne organisms in other parts of a cotton spinning mill were similar to and had much the same percentage distribution as those in the cardroom of the same mill on the same occasion, though the total count per cubic foot might be different. This, however, was less true of the waste mill, where the devil-room showed a much higher count than the card-room, but a lower percentage of Bacillus which was statistically significant, though it remained much the most numerous type.

\section{Summary}

A study has been made of the relative incidence of the genera of bacteria present in the air of cotton mills. Bacillus is the most prominent, followed by Flavobacterium, Achromobacter, Aerobacter, Corynebacterium, Actinomyces, and Micrococcus. No true anaerobes have been isolated and organisms characteristic of the respiratory tract were rarely found.

This form of distribution was essentially the same at all stages of processing although the number of organisms per cubic foot was very different.

\section{REFERENCE}

Bergey, D. H. (1948). " Manual of Determinative Bacteriology", 6 th ed. ed. Breed, R. S., Murray, E. G. D., and Hitchens, A. P. Baltimore. 